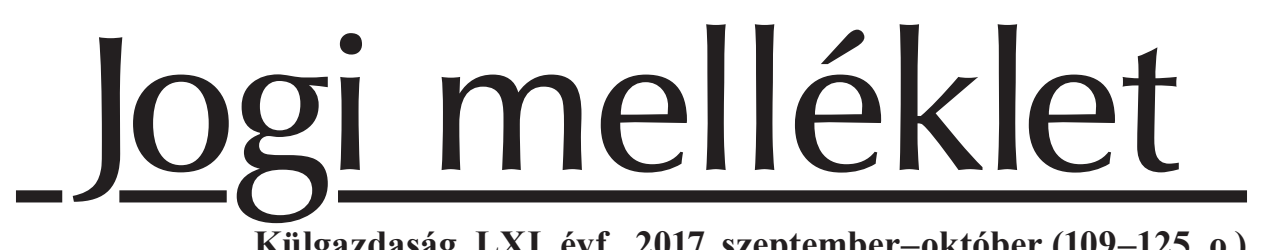

Külgazdaság, LXI. évf., 2017. szeptember-október (109-125. o.)

\title{
Közteherviselés és adóeljárás elvi megközelítésben Szlovákia és Magyarország példáján keresztül NYERGES ÉVA
}

A szuverén állam egyik alapvetö funkciója a közbevételek gyüjtése. A társadalom közös szükségleteinek megteremtése sokrétü feladat, hiszen mind a szükséges források elöteremtése, mind az újraelosztás szabályainak elöirása során számos érdeket szükséges összehangolni. Az adókötelezettség elvének deklarálása az adózás elvi, eszmei alapja, ami végső soron az adóeljárásban valósul meg. Az adóterhek megfizetése a közteherviselés elvén nyugszik, amely alkotmányos szintü kötelezettséggé emeli az állampolgárok egymás iránt vállalt szolidaritásának kifejezödését. Az adóeljárás ennek processzuális kereteit teremti meg, a szervezeti és eljárási szabályok biztositják az adórendszer müködését. Jelen irás tehát az adózási folyamat két végpontját - más aspektusból annak célját és eszközét - elemzi, mégpedig hazánk és a szomszédos Szlovákia jogszabályainak vizsgálatán keresztül. Ennek során a közteherviselés elvének megjelenése és az adóeljárási jogok összehasonlitására kerül sor, értékelve a két vizsgált állam szabályainak hasonlóságait és különbségeit.

Journal of Economic Literature (JEL) kód: K34 - Tax law.

https://doi.org/10.47630/KULG.2017.61.9-10.109

Dr. Nyerges Éva, PhD-hallgató (Széchenyi István Egyetem Állam- és Jogtudományi Doktori Iskola, Kereskedelmi, Agrár- és Munkajogi Tanszék). E-mail: eva@drnyerges.com. 
„Things as certain as death and taxes..."

Daniel Defoe: The Political History of the Devil, 1726.

\section{Bevezető}

A közteherviselés szorosan kapcsolódik az államisághoz. A szuverén állam egyik alapvető és klasszikus funkciója a közbevételek gyűjtése: az adószedés története évezredekre nyúlik vissza. A közteherviselés feltehetően valóban szükségszerü velejárója az állami létnek. Habár az adó mértéke, beszedésének módja koronként eltérő lehet, annak szükségessége aligha vitatható. Ugyanis a civilizált életmód a társadalom tagjai számára olyan igényekkel jár, amelyek egyénileg nem kielégíthetők, vagy csak jelentős nehézségek árán. Ezek legtöbbje közszükséglet. Ezeknek a szükségleteknek a biztosítása jellemzően állami feladat, és közös vonásuk, hogy kisebb-nagyobb értékben - közérdek füződik hozzájuk.

Bár az adófizetés jogossága, legitimitása időről időre megkérdőjeleződik, mégis elmondható, hogy a társadalom többsége alapvetően elfogadottnak tekinti. Ennek magyarázata pedig az imént említett közérdekben kereshető, ami - noha igen nehezen megfogható kifejezés - igazolja az egyéni javak elvonását és áthatja a teljes állami működést. A közbevételekből fedezi ugyanis az állam a közkiadásokat, a közkiadások pedig jellemzően a közfeladatok teljesítéséhez kapcsolódnak. Ahogy a közérdek, úgy a közteherviselés jelensége sem írható le egyszerúen, tekintettel arra, hogy egészen messzire vezető elméletek adják jellegadó ismérveit. A közteherviselés ennek megfelelően több oldalról megközelíthető fogalom, jelentéstartalma különböző nézőpontból eltérö lehet.

Kétségtelen, hogy állami keretek között szerveződő társadalomban az adózás, a közteherviselés szinte kivétel nélkül jelen van a polgárok életében. Jóllehet, európai viszonylatban - és így a szük értelemben vett kelet-közép-európai régióban is - a közteherviselés jellege és teljesítésének módja többnyire hasonlóan történik a különböző országokban, ám az eljárási szabályokban és az adózást meghatározó jogszabályok szövegezésében lényeges eltérések mutatkoznak. Alábbi sorok - a teljesség igénye nélkül - a közteherviselés alkotmányos tartalmára, legitimitásának alapjaira vonatkozó gondolatokat igyekeznek csokorba gyüjteni. A rövid cikk hazánk és szomszédos Szlovákia jogának egybevetésére törekszik, mégpedig az adózás egyes kérdéseinek szemszögéből. A vizsgálat tárgyát elsősorban a közteherviselés megjelenésének mikéntje képezi, emellett pedig - illetőleg ezzel összefüggésben - az adóeljárást átható elvek kifejeződésére fókuszál a különböző nemzeti adóeljárási jogszabályok ismertetésén át. 
Közteherviselés és adóeljárás elvi megközelítésben Szlovákia és Magyarország...

\subsection{Töredékek a közteherviselés történetéből}

A közteherviselés - úgy tűnik - együtt jár az állami léttel, s már meglehetősen korai forrásokban is találunk az adózással kapcsolatos utalásokat, rendelkezéseket. Charles Adams sokat idézett szavaival élve az adózás nem más, mint a szervezett társadalom múködésének ára. ${ }^{1}$ Nincs olyan társadalom, amelyben nem volt, ne lett volna adózás.

Az ókori társadalmak mindegyikéről elmondható, hogy a szervezett állam a lakosok egy részének segítségét is igénybe vette a kiadások fedezésére: az önkéntes hozzájárulások helyét átvették a rendszeres időközönként kötelezően beszolgáltatandó termékek, kötelezően végzendő szolgáltatások. A termelésben résztvevők és az adományok kedvezményezettjei kezdtek távolodni egymástól, egyre inkább kényszerrel kellett a közösségi müködés gazdasági alapjait megteremteni. ${ }^{2} \mathrm{~A}$ legtöbb vallási eredetű szentkönyvben, így a keresztény Bibliában is szerepel adózásra vonatkozó rendelkezés, hiszen kifejezetten szabályozta a tized viselésének kötelezettségét, és gyakran említik az adózás gyökereként az - egyesek szerint egyébként félreértett - idézetet: „Adjátok meg a császárnak, ami a császáré, és az Istennek, ami az Istené."’3 De már a kezdeti iszlám is az öt kötelesség között nevesíti a zakát, vagyis a közadó szolgáltatását, amellyel minden mohamedán ember a gyülekezet közcéljainak előmozdítására vagy épp a szegények felsegítésére a közpénztárhoz hozzájárulni köteles. ${ }^{4} \mathrm{Az}$ adózás tehát átível az állam történetén. Az intézményesített adózás, az adórendszer történetében máig Adam Smith elmélete a meghatározó. Smith - amellett, hogy az adóval szemben támasztott követelményeket is kimondta (általános, igazságos, olcsó és kényelmes legyen) - elsőként fogalmazta meg, hogy minden polgár a képességei szerint köteles az adózást viselni. ${ }^{5}$

\subsection{A köz terhei és az adófizetés kapcsolata}

Néhány gondolatot - mintegy bevezetöül - általánosságban is célszerủ az állami közkiadások pénzügyi alapjainak szentelni, hiszen az állami struktúra müködtetése

${ }^{1}$ Adams [2001], idézi: Juhász [2014].

2 Juhász [é.n.].

${ }^{3}$ Biblia, Újszövetség, Máté evangéliuma, Mt.22.21. (Katolikus Biblia, Szent István Társulat, 1996)

${ }^{4}$ Marczali [1900].

Smith [1776], idézi: Klicsu [1991]. 
és fenntartása elképzelhetetlen az anyagi feltételek megteremtése nélkül. E vonatkozásban pedig a szükséges források biztosításának egyik alapvető pillérét képezik az adóbefizetések. A közteherviselésből eredő pénzeszközök aránya az állami bevételek körében - hazánkban - igen jelentős, az tehát nélkülözhetetlen az állami feladatellátás megvalósításához.

Nehezen volna vitatható az az álláspont, amely szerint amennyiben Magyarország „hosszú távon közösségként szeretne létezni és európai értelemben vett demokráciát finanszírozni, úgy ennek vagyoni, pénzügyi lehetőségeit meg kell teremteni." ${ }^{\circ}$ A közszükségletekre és - az igen szerteágazó - közszolgáltatásokra vonatkozó igény olyan alapvető elvárás a társadalom tagjai oldaláról, amelyet - lényegében szinte tudattalanul - magától értetődőnek tartanak a 21. század polgárai. Az állam oldaláról ez a kötelezettség - tartalmát, korlátait és föként forrásait tekintve - azonban korántsem ilyen egyszerü. Ebből az aspektusból ugyanis alapvetően célokként és eszközökként tekinthető a feladat, melynek ellátása során elsősorban arra az alapvető kérdésre szükséges válaszolni, hogy mit finanszírozzon az állam. Az állami feladat-meghatározás és a költségek fedezetének megteremtésének útja egyfajta jövedelemátcsoportosításon keresztül zajlik: elosztási, újraelosztási kérdés. ${ }^{7}$

Az állam - egyéb funkciói mellett - alapvetően ökonómiai jelenség. A gazdasági funkciót a közigazgatási és közgazdasági tudományos irodalom az állam klaszszikus funkciói között tartja számon. A gazdasági szerep alapvetően gazdálkodást jelent, leegyszerüsítve bevételek és kiadások dinamikus mozgását. A jól müködő adórendszer pedig fontos része minden gazdasági rendszernek. Ám ha arra a kérdésre keressük a választ, hogy valójában milyen egy jól működő adórendszer, vagy milyennek kellene lennie, úgy bizonyosan nem találunk egységes álláspontot. ${ }^{8} \mathrm{Az}$ egymást részben fedő, mégis bizonyos tekintetben mégis egymást kizáró feltételek - mint az igazságosság, hatékonyság, egyszerüség, effektivitás - egyidejủleg kell, hogy érvényre jussanak az adórendszer meghatározásakor. Amint arra számos szerző rámutat, a modern adórendszerrel szemben támasztott követelmények nincsenek teljesen összhangban, ezért az elvárásoknak való megfelelés valóban kihívást jelenthet. ${ }^{9}$ Térségünkben a helyzet sajátosságát az adja, hogy a kelet-közép-európai posztkommunista államok 1989-ben új alapokról indulva kellett, hogy megteremtsék saját új adórendszerüket. Jelen írásban vizsgált mindkét állam esetében elmondható, hogy

${ }^{6}$ Simon [2011], 1. o.

7 Simon [2011], 3. o.

${ }^{8}$ Árendás [2006], 3. o.

9 Balláné [2006], 68. o. 
híján voltak e téren a saját tapasztalatoknak, egységesen alkalmazható külföldi példák pedig ugyancsak nem álltak rendelkezésre. ${ }^{10}$

\section{A közteherviselés alkotmányos alapjai a vizsgált államokban}

A jogforrási hierarchia elvéből következően mindenekelött a közteherviselés alkotmányos alapjait célszerủ megvizsgálni. A konkrét adófizetési kötelesség előírása, illetve az állam költségeihez való hozzájárulás teljesítése ugyanis (modern jogrendszerben) pontosan meghatározott jogalkotási folyamat eredménye. A normatív kötelezettség kimondása kizárólag olyan rendben történhet, melyben a norma megszületése a jogforrási láncon az alapnormáig visszavezethető, és amelyben az alkotmányosság követelményét garanciális szabályok biztosítják.

A következőkben az adóztatás elvi alapját jelentő közteherviselési kötelezettség áttekintésére kerül sor, mégpedig a két vizsgált állam nemzeti alapnormájában való megjelenésének ismertetésével. Az állam kiadásaihoz való kötelező hozzájárulás megfogalmazása körében elsőként a szlovák Alkotmány rendelkezéseinek vizsgálata, ezt követően hazánk Alaptörvényének ismertetése következik. Lényeges, a vizsgálat szempontjait és jelentőségét kijelölő feltevés, hogy a két állam rendelkezéseinek egybevetésével elsősorban a szabályozási technika válik összehasonlíthatóvá. Önmagában a közteherviselés elvének kifejeződéséből tehát a gyakorlati megvalósításra vonatkozóan érdemi következtetések nem vonhatók le.

\subsection{Az adózás alapjai a szlovák Alkotmányban}

Az adórendszer felépítése, a közteherviselés módjának és mértékének meghatározása Szlovákia államszervezésében és gazdasági múködtetésében is kiemelt jelentőségü kérdés. Ahogy a legtöbb államban, úgy Szlovákiában is elmondható, hogy az adó kérdése az aktuálpolitikában is lényeges szerepet játszik. Jóllehet az adózást érintő döntésekkel kapcsolatban felhozható az a vád, hogy inkább ideológiai, semmint közgazdasági érdekek állnak mögöttük ${ }^{11}$ az elmúlt évek adóreformjai mégis világosan rámutatnak a kérdés fontosságára.

${ }^{10}$ Árendás [2006], 3. o.

${ }^{11}$ Meravý [2012]. 
A közteherviselés, a közös állami kiadásokhoz való hozzájárulás egyéni kötelezettsége a szlovák alkotmányos rendelkezésekben nem fejeződik ki, konkrét kötelességként legalábbis nem fogalmazódik meg. Adót természetesen Szlovákiában is fizetnek a természetes személyek és más jogalanyok egyaránt, vagyis a kötelezettség „benne rejlő” módon mégis jelen van a jogszabályokban. Mindez azonban olyan jogalkotási technikával valósul meg, hogy azt elvi szinten nem fogalmazza meg az alapnorma. A Szlovák Köztársaság Alkotmánya mindössze annyit deklarál 59. cikkelyében, hogy „Léteznek állami és helyi adók és illetékek.” Rögzíti továbbá a jogalkotásra vonatkozó alkotmányos kötelezettséget, mely szerint: „Adók és illetékek csak törvénnyel vagy törvény alapján vethetök ki." 12

A szlovák Alkotmány szabályainak vizsgálata során megállapítható tehát, hogy nincs a magyar alkotmányos hagyományokban fellelhető klauzulának megfelelő rendelkezés az alapnormában. A közteherviselés elve mindössze egy rövid utalásban fejeződik ki, amely tulajdonképpen a közterhek létezését rögzíti. Lényeges, hogy a központi szintủ (állami) adók mellett a helyi adókat is nevesíti a szlovák jogrendszer alapját jelentő normaszöveg. A helyi önkormányzatok bevételeit már az alkotmány szintjén biztosítja a szabályozás, mely tényből - a helyi közösség kiadásaiban való kötelező hozzájárulás ténye mellett - a szlovák önkormányzatiság jelentőségére is lehet következtetni.

Az Alkotmány rendelkezésének második bekezdése az adókra vonatkozó normák törvényi szintủ szabályozását követeli meg. Deklarálja ugyanis azt a jogalkotási követelményt, amely szerint adók és illetékek kizárólag törvénnyel vagy törvény alapján vethetök ki. A törvényi ranghoz kötött jogalkotás igényéből az következik, hogy a szlovák jogrendszer - hasonlóan a magyar szabályozáshoz - ugyancsak megköveteli, hogy a kötelező állampolgári hozzájárulás teljesítésének módja és mértéke mögött a parlamenti konszenzus álljon. E mögött a garanciális jelentőségủ kikötés mögött feltehetőleg a tulajdonkorlátozás intézményének feltételhez kötése rejlik, amely jellegében jogállami szabályozásra mutat.

\subsection{A közteherviselési kötelezettség Magyarország Alaptörvényében}

A közösség terheihez való hozzájárulás hazánkban Alaptörvénybe foglalt kötelezettség. Az adókivetés és -megfizetés alkotmányos meghatározottságát a jogállami normaalkotás, végső soron pedig a demokratikus legitimáció elve követeli meg.

12 Tt. 460/1992 A Szlovák Köztársaság alkotmánya 59. cikkely. 
Közteherviselés és adóeljárás elvi megközelítésben Szlovákia és Magyarország...

A szabályozás magas szintjének igénye nem egyedülálló jelenség, hiszen nemcsak hazánk, hanem a polgári államok jogrendszereiről általában is elmondható, hogy a közterhekhez való hozzájárulást alaptörvényben mondják ki. ${ }^{13}$

Alaptörvényünk az alapjogok körében, a Szabadság és felelősség címủ fejezetben rögzíti a közös közteherviselés egyéni kötelességét. Az alkotmányos szintre emelt passzus alapján „teherbíró képességének, illetve a gazdaságban való részvételének megfelelően mindenki hozzájárul a közös szükségletek fedezéséhez." ${ }^{14}$ Noha a hozzájárulás egyéni kötelezettségként fogalmazódik meg az alapjogok sorában, mégis egyúttal pozitív tartalmat is hordoz: a társadalom többi tagja számára ugyanis biztosítékot nyújt a közpénzügyi alapok kölcsönös és közös megteremtésére.

Noha a tételes hazai joganyag nem ad definíciót az adó fogalmára, mind az igazgatási, mind a büntetőjogi jogszabályok felsorolással körülírják, hogy a tényállásszerủ magatartások megítélése körében mit tekintenek állami bevételnek. A magyar adójog tehát nem tartalmazza az adó fogalmának a meghatározását, az adózás rendjéröl szóló törvény ${ }^{15}$ a tárgyi hatályának a meghatározása körében sorolja fel azon pénzügyi tételeket, amelyekre saját alkalmazási köre kiterjed. Hasonló metódust alkalmaz büntetőjogi kódexünk is, hiszen a büntetőjogi adófogalom ugyancsak mellőzi a definiálást. Mind az adóeljárási, mind a büntetőjogi fogalomhasználat vonatkozásában elmondható, hogy az adó kifejezés tágabb, mint a szoros értelemben vett anyagi jogszabályokban adó elnevezéssel megjelölt befizetési formák köre. ${ }^{16}$

A „közteher” kifejezés az adó fogalmához szorosan kapcsolódó fogalom: azt a jogi és közgazdaságtani irodalom gyakran használja, az voltaképpen az adózással összefüggő elméletek egyik kulcsfogalma. Korábbi Alkotmányunk kifejezett kötelezettségként írta elő a közterhekhez való hozzájárulást, az Alaptörvény viszont a közteherviselés alapklauzulájában inkább a közös szükségletekhez való hozzájárulásként fogalmazza meg. Az Állam címü fejezet 40. cikkében azután mégis hivatkozik rá, ami arra utal, hogy a jogintézményt alapvetően elfogadottnak és kötelezőnek tekinti. Ugyanakkor érdemes rá felhívni a figyelmet, hogy sem az Alkotmány, sem az Alaptörvény, sem más jogforrásunk nem határozza meg, valójában mit tekint köztehernek.

Az Alaptörvény XXX. cikke tekinthető a közteherviselési kötelezettséget alapvetően meghatározó rendelkezésnek. Ennek értelmében „teherbirró képességének,

${ }^{13}$ Bihari [2007], 21. o.

${ }^{14}$ Magyarország Alaptörvénye (2011. április 25.) XXX. cikk (1) bekezdés.

15 2003. évi XCII. törvény az adózás rendjéröl (Art.).

${ }^{16}$ Molnár [2011], 51-53. o. 
illetve a gazdaságban való részvételének megfelelöen mindenki hozzájárul a közös szükségletek fedezéséhez". A közkiadásokhoz való hozzájárulás tehát alkotmányos alapelvként jelenik meg hazánk Alaptörvényében (csakúgy, mint a korábbi Alkotmányban). S míg a régi Alkotmányunk bevételi oldalról közelítette meg ezt a kötelezettséget, mai Alaptörvényünk viszont a közszükségletekhez való kiszámítható hozzájárulást tekinti az elv lényegének, vagyis annak kiadás jellegét helyezi előtérbe. ${ }^{17}$

Érdemes azonban figyelembe venni, hogy a közteherviselési alapklauzulaként értelmezett XXX. cikk mellett Alaptörvényünk több más helyen is tartalmaz olyan rendelkezést, amelyből levezethető az állam terheinek közös viselése. Ilyen a Nemzeti Hitvallásban szereplő, a rászorultak megsegítésére vonatkozó nyilatkozat, vagy épp a tulajdonhoz való jog szabályai között elhelyezett rendelkezés, amely szerint „a tulajdon társadalmi felelősséggel jár". ${ }^{18}$ Valamint a további, szintén kötelezettséget megfogalmazó alaptörvényi rendelkezés szerint mindenki felelős önmagáért, amely passzus második fordulata már a többiekért való felelősségvállalás kötelezettségével fejeződik be: „képességei és lehetőségei szerint köteles az állami és közösségi feladatok ellátásához hozzájárulni" ${ }^{19}$

Hazánkban a közteherviselés - mint a polgári jogegyenlőség egyik általános alapelve - 1848-ban vált törvényen alapuló kötelezettséggé. A hagyományos magyar közjogban a közteherviselés fogalma nem korlátozódott csupán az adófizetésre, az ugyanis magában foglalta bizonyos közhivatalok viselését is, így a községi bírói hivatal ellátását, a közmunkavégzést, a katonai dologi szolgáltatásokat vagy épp a közveszély esetén teljesítendő feladatokat. ${ }^{20}$

A szocialista tervgazdálkodlás keretei között - ideológiai megfontolásból - nem jelent meg az Alkotmányban az adókötelesség. Ennek ellenére azonban léteztek olyan, alkotmányos szintnél alacsonyabb jogszabályok, amelyek a költségvetésbe való befizetési kötelezettséget írtak elö. A gazdasági értelemben vett rendszerváltással összhangban az Alkotmány szövege csak 1989. október 23. napja óta tartalmaz közteherviselésre vonatkozó rendelkezést.

A közteherviselés alkotmányos alapelvként jelenik meg hazánk Alaptörvényében is csakúgy, mint a korábbi Alkotmányban. Lényeges különbség azonban, hogy régi Alkotmányunk bevételi oldalról közelítette meg ezt a kötelezettséget, mai Alap-

${ }^{17}$ Erdös [2011], 46. o.

${ }_{18}$ Magyarország Alaptörvénye (2011. április 25.) XIII. cikk (1) bekezdés.

19 Alaptörvény O) cikk.

${ }^{20}$ Tomcsányi [2009], 264. o. 
Közteherviselés és adóeljárás elvi megközelítésben Szlovákia és Magyarország...

törvényünk viszont a közszükségletekhez való kiszámítható hozzájárulást tekinti az elv lényegének, vagyis annak kiadás jellegét helyezi előtérbe. ${ }^{21}$

Az Alkotmány és az Alaptörvény közteherviselési klauzulájának összehasonlítása

\begin{tabular}{|c|c|}
\hline Alkotmány 70/I. § & Alaptörvény XXX. cikk \\
\hline $\begin{array}{l}\text { Minden természetes személy, jogi személy és } \\
\text { jogi személyiséggel nem rendelkező szervezet } \\
\text { köteles jövedelmi és vagyoni viszonyainak meg- } \\
\text { felelően a közterhekhez hozzájárulni. }\end{array}$ & $\begin{array}{l}\text { (1) Teherbíró képességének, illetve a gazdaság- } \\
\text { ban való részvételének megfelelöen mindenki } \\
\text { hozzájárul a közös szükségletek fedezéséhez. }\end{array}$ \\
\hline
\end{tabular}

\section{Adóeljárási alapelvek határon innen és túl}

Leegyszerüsítve tehát elmondható, hogy amikor adót fizetünk, lényegében együttmüködünk polgártársainkkal. Ennek a kooperációnak a végeredménye mindannyiunk számára előnyösebb lehet az olyan együttmüködésnél, amelyben nincs adóztatás. Megvalósításához viszont azonnali költségeket kell elszenvednünk, mivel az adófizetés az egyéni költségvetési halmaz szükítését jelenti. ${ }^{22}$

Az adó általános értelemben kötelezően teljesítendő pénzbeli szolgáltatás, amelyet az egyének, illetőleg a szervezetek az állam felé közvetlen ellenszolgáltatás nélkül teljesítenek. Az adó jogi-jogviszonytani értelemben a közhatalom által feljogosított közigazgatási szerv (adóhatóság) és az egyén vagy szervezet közötti viszony, amelyet anyagi és eljárási normák határoznak meg; és amelyek anyagi és eljárási jogviszonyokban realizálódnak, mégpedig az egyének jövedelmi-vagyoni helyzetéhez igazodó jövedelemközpontosítás érdekében. ${ }^{23}$

Minden korban alapvető kérdés, hogy a közösség előtt álló és közösen megoldandó feladatok megoldásában milyen mértékủ szerepet vállaljon az állam. Mindezen jogosítványok és tevékenységek gyakorlását az állami közpénzügyi rendszer hivatott megvalósítani, amely a közpénzek speciális, több csatornából álló rendszere. ${ }^{24}$

A közbevételek begyüjtése és központosítása a mai állami berendezkedésben tipikusan sokrétủ és kiterjedt eszköz- és intézményrendszer útján történik. Tekintve,

${ }^{21}$ Erdös [2011], 46. o.

${ }^{22}$ Méder-Simonovits-Vincze [2012], 1086. o.

${ }^{23}$ Földes [2007], 361-362.

${ }^{24}$ Molnár [2011], 47. o. 
hogy az állam anyagi alapjainak és gazdasági stabilitásának megteremtésében az adóbevételek kulcsfontosságúak, így azok beszedésére akár a legitim kényszer eszközeinek alkalmazása is nyitva áll.

Az adózás eljárási szabályai - hasonlóan az anyagi jogforrásokhoz - mindkét vizsgált országban külön törvényben kerültek megfogalmazásra. Az adózás rendjét kimondó passzusok mind a két esetben meghatároznak alapelvi szintủ rendelkezéseket, amelyeknek a teljes adóeljárás során érvényesülniük kell, és amelyek - elvi jellegükből adódóan - kétség esetén a jogértelmezést segítik. Hazánk és a szomszédos Szlovákia adózásra vonatkozó szabályainak összevetésének körében az alábbiakban mindenekelőtt a szlovák szabályok rövid bemutatása következik.

\subsection{Adórendszer és adóeljárás Szlovákiában}

Szlovákia adórendszere Európa más államainak adórendszeréhez hasonló adónemeket határoz meg. Az adórendszerre 1993 elött alapvetően a közvetlen adók voltak jellemzőek (jövedelemadó, földadó, mezőgazdasági adó), emellett - egyetlen kivételként - a forgalmi adó is jelen volt. 1993 és 2004 között a közvetett adózás alkalmazási köre kibővült a hagyományos jövedéki termékeket terhelő fizetési kötelezettséggel, így adókötelessé vált a szeszes italok, ásványi olajok és dohánytermékek értékesítése.

2004 óta a közösségi joghoz való közelítés értelmében az uniós jogalkotás elemeinek átvétele jellemzi Szlovákiát. Elterjedtek a hagyományos adókategóriák: jövedelemadók, helyi adók, hozzáadottérték-adó is gyarapítja a szlovák államkasszát.

A szlovák állami adóhatóság a jogérvényesülést adóeljárás lefolytatásával biztosítja, amely magában foglalja az ellenőrzések lebonyolítását is. Az adóellenőrzés általában az adózó írásban történő értesítésével kezdődik, és az ügyfél által - bizonyos feltételek mellett - annak elhalasztása is kérhető (ez alól kivételt képez a büntetőeljárással összefüggő eljárás). Az ellenőrzés széles körü, a bizonylatok hitelességének vizsgálata vagy az adó-visszaigénylés megalapozottsága egyaránt az eljárás alapját képezhetik..$^{25}$

${ }^{25}$ Kaffka [2013]. 
Szlovákiában az adózás rendjének szabályait az 563/2009 törvény tartalmazza. ${ }^{26}$ A jogszabály megnevezése meglehetősen részletesen jelöli ki a szabályozási tárgykört a következők szerint: „Törvény az adó kezeléséröl (adózás rendje) és egyes törvények módositásáról és kiegészitéséről." Első paragrafusa a szabályozás tárgyát és hatályát jelöli meg, amely szerint a törvény az adókezelés rendjét, az adóalanyok és más személyek adókezelés kapcsán létrejövő jogait és kötelezettségeit határozza meg. Az alapfogalmak cím alatt a törvény mind az eljárásokat, mind az egyes adónemeket, illetve egyéb fizetési kötelezettségeket, továbbá az eljárást és egyéb eljáráshoz kapcsolódó kifejezéseket törekszik tisztázni.

3.1.2. Adóeljárási jogok a „szlovák Art.”-ben

Az adókezelés alapelvei körében a törvény meglehetősen szűkszavúan határozza meg azokat az elvi szintủ rendelkezéseket, amelyeknek az adóeljárás során kötelezően érvényesülniük kell.

a) A törvény az alapelvek között elsőként a törvényben biztosított jogok védelmét nevesíti, amely szerint „az adókezelés során (...) az állam és a települések érdekeinek védelme mellett (...) figyelmet forditanak az adóalanyok és más személyek jogainak és törvényben védett érdekeinek betartására".

b) Az együttmüködés és tájékoztatás kötelezettségét szintén kiemeli a jogalkotó, mely szerint ,az adóhatóság az adókezelés során szoros együttmüködést folytat az adóalannyal és más személyekkel, és tájékoztatja öket az eljárási jogokról és kötelességekröl".

c) Azonos bekezdésben kitér továbbá a hatóság eljárási kötelezettségére, amely alapján ,az adó kezelöje köteles foglalkozni minden olyan üggyel, amely az adókezelés tárgya, és haladéktalanul, indokolatlan késedelem nélkül kezelni azt, valamint a legmegfelelöbb eszközöket használni, amelyek az adó pontos meghatározásához és kivetéséhez vezetnek".

d) A szabad bizonyítás elve ugyancsak megjelenik szlovák adóeljárásban: „az adó kezelöje a bizonyitékokat saját mérlegelése szerint értékeli, vagyis minden bizonyitékot egyedileg és kölcsönös összefüggéseiben, miközben tekintettel van mindenre, ami az adó kezelése során nyilvánvalóvá vált."

${ }^{26}$ 563/2009 törvény az adó kezelésről (adózás rendje) és egyes törvények módosításáról és kiegészítéséről. 
e) Deklarálja a törvény az eljárás bizalmas jellegét is, amely szerint az föszabály szerint nem nyilvános, valamint „az adóigazgatási müveletekröl nem közölhetök képi, hang-és audiovizuális felvételek".

f) A hivatalbóliság elve szintén megjelenik az eljárási elvek között, ugyanis rögzíti, hogy „az adóhatóság köteles az adóigazgatással kapcsolatos müveleteket saját kezdeményezésböl is végrehajtani, amennyiben az adókövetelés keletkezésének vagy létezésének törvényi feltételei teljesülnek, akkor is, ha az adóalany részben vagy teljes mértékben nem tett eleget kötelességeinek".

g) A valódiság védelmében meghatározza továbbá a törvény a rendeltetésellenes nyilatkozatok kirekesztésének a lehetőségét is, mely alapján az adóhatóság ,a jogi lépések valós tartalmát” veheti figyelembe, szemben a „gazdaságilag megalapozatlan”, illetve olyan nyilatkozatokkal és tényekkel, melyek az adózási kötelesség célzott elkerülésére vagy vak adózási előny megszerzésre irányulnak.

h) Az adóalanyok törvény elötti egyenlőségét a 3. § (7) határozza meg, amely szerint ,az adóalanyok az adókezelés során egyenlö jogokkal és kötelességekkel rendelkeznek”, az egyenlő eljárást követeli meg továbbá az indokolatlan különbségtételt tiltó következő rendelkezés is: „Az adóhatóság gondoskodik arról, hogy a tényszerüen azonos esetekben ne jöjjenek létre indokolatlan különbségek."

i) Az együttmüködési kötelezettség teljesítését a törvény nemcsak a hatóság, hanem az adóalanyok oldaláról is megköveteli, akik kötelesek „az adókezelés során szorosan együttmüködni az adóhatósággal”.

3.2. Az adózás rendjének hazai alapelvei

Magyarországon az adóeljárás szabályait az adózás rendjéről szóló 2003. évi XCII. törvény (a továbbiakban: Art.) tartalmazza. A jogszabály meglehetősen hoszszú, és igen részletesen dolgozza ki az eljárási szabályokat. Az alapelvekre vonatkozó rendelkezések a törvény első bekezdéseiben találhatók, ám az Alapelvek cím alatt nevesített szabályokon túl a törvény külön fejezetben tartalmazza az ellenőrzés során megvalósuló jogokat és kötelezettségeket mind az adózó, mind az adóhatóság vonatkozásában, valamint az adótitok szabályait is külön fejezetben bontja ki. Az alábbiakban az adóeljárást átható alapelvek vázlatosan, a teljesség igénye nélkül kerülnek bemutatásra.

a) A jogalkotó alapelvi szinten rögzíti magát a törvény célját, kiemelve a törvényesség és eredményesség együttes érvényesülését, amely e szerint „az adózás 
Közteherviselés és adóeljárás elvi megközelítésben Szlovákia és Magyarország...

rendjének, az eljárás törvényessége és eredményessége érdekében az adózók és az adóhatóságok jogainak és kötelezettségeinek egységes szabályozása”.

b) A rendeltetésszerü joggyakorlás követelménye szintén alapelvi jelentőséggel bír, amely az adózót és az adóhatóságot egyaránt kötelezi. Külön megfogalmazza emellett az Art., hogy a hatóságnak a mérlegelés során is szem előtt kell tartania e követelményt. A 2. § (1) bekezdés külön is megfogalmazza, hogy „,az adójogviszonyokban a jogokat rendeltetésszerüen kell gyakorolni. Az adótörvények alkalmazásában nem minösül rendeltetésszerü joggyakorlásnak az olyan szerződés vagy más jogügylet, amelynek célja az adótörvényben foglalt rendelkezések megkerülése, mely utóbbi fordulat az adóalanyok vonatkozásában értelmezhető.

c) A megkülönböztetés tilalma hazánk jogrendszerében is alapelvi szintủ kötelezettség, amely az Art.-ben a következőképpen jelenik meg: „Az adóhatóság minden ügyben megkülönböztetés nélkül, a törvényeknek megfelelöen köteles eljárni és intézkedni.” Ebböl az elvböl kiindulva további, speciális követelmény, hogy az adóalanyok ,ellenörzése során ugyanazt a vizsgálattal érintett és már minösitett jogviszonyt az adóhatóság nem minösitheti adózónként eltérően, a jogviszony egyik alanyánál tett megállapitásait hivatalból köteles figyelembe venni a jogviszony másik alanyának ellenőrzése során.” Ugyancsak e körbe sorolható, hogy (nemzetközi szerződés eltérő rendelkezése hiányában) „, a magánszemélyek adóügyeiben tilos állampolgárság szerint megkülönböztetést tenni”.

d) Az együttműködési és tájékoztatási kötelezettség ugyancsak kifejezésre kerül: „az adóhatóság az adózónak (...) szükséges tájékoztatást megadja, az adóbevallás, az adóbefizetés rendjét vele megismerteti, az adózót jogainak érvényesitésére figyelmezteti. Az adózó köteles a jogait jóhiszemüen gyakorolni és elösegíteni az adóhatóság feladatainak végrehajtását."

e) Alapelvként jelenik meg a méltányosság és a fizetési könnyítés követelménye is, amely kifejezetten a - nyilvánvaló közhatalmi fölényben lévő - adóhatóságot kötelezi. E szerint „az adóhatóság köteles méltányosan eljárni, és ha a (...) feltételek fennállnak, az adótartozást mérsékli, illetve fizetési könnyitést engedélyez".

f) A valódiság védelme érdekében az adóhatóság hazánkban is jogosult a valós tényeknek megfelelően értékelni az adott jogi helyzetet, ám a megfogalmazás a szlovák szabályoktól némileg eltérő tartalmat hordoz. Az Art. alapján „a szerződést, ügyletet és más hasonló cselekményeket valódi tartalmuk szerint kell minösiteni. Az érvénytelen szerzödésnek vagy más jogügyletnek az adózás szempontjából annyiban van jelentösége, amennyiben gazdasági eredménye kimutatható." Részletesen körülírt diszpozícióval rendelkezik továbbá a törvény a kapcsolt vállalkozások közötti 
„alul- vagy felülszámlázás” esetkörére is: „A szokásos piaci ártól eltérő szerződési feltételeket alkalmazó kapcsolt vállalkozások ügyleteit adózási szempontból a szokásos piaci ár alapulvételével kell minösiteni..."

g) Az alapelvek között jelenik meg továbbá a jogellenes ügyletekre is kiterjedő adókötelezettség, vagyis az, hogy az adókötelezettség szempontjából nincs annak jelentősége, ha fiktív, rosszhiszemü, illetve jogellenes az az ügylet, amelyből a bevétel vagy jövedelem, illetve bármely „adóalap-keletkeztető” tény származik. Kimondja ugyanis az Art., hogy „az adókötelezettséget nem befolyásolja az, hogy a magatartás (cselekmény, mulasztás) törvényi rendelkezésbe ütközik, vagy sérti a jó erkölcsöt”.

h) Nemzetközi elemet tartalmazó adótényállások esetére fogalmaz meg továbbá hazánk számára adóztatási jogot az a rendelkezés, amely alapján amennyiben nemzetközi szerződés értelmezése azt eredményezi, hogy „az adott jogviszonyból származó jövedelmet egyik állam sem tekinti belföldön adóztathatónak, akkor Magyarország nem mentesíti ezt a jövedelmet az adóztatás alól”.

i) Szintén az alapelvek között kapott helyet az adóhatóság számára biztosított igen erős jogosultságot meghatározó - eszköz, a becsléssel történő adómegállapítás lehetősége. E szerint „az adóhatóság az adót az összes körülményre, különösen a rendeltetésszerü joggyakorlás esetén irányadó adófizetési kötelezettségre figyelemmel - ha az adó alapja így nem állapitható meg, becsléssel - állapítja meg". ${ }^{27}$

\section{4. Összegzés}

A két ország adózásra vonatkozó egyes szabályainak összevetésekor mindenekelőtt az a megállapítás tehető, hogy Magyarországon a jogi szabályozás lényegesen kiterjedtebb és részletesebb, mint Szlovákiában. Mind az alkotmányos szintủ rendelkezések, mind az adóeljárási törvényben meghatározott szabályok esetében elmondható, hogy hazánk ide vonatkozó szabályai mennyiségüket tekintve is és tartalmilag is túlsúlyban vannak a szlovák szabályozáshoz képest.

Míg Magyarország Alaptörvénye kifejezetten rögzíti a közteherviselés kötelezettségét, mi több, az alapklauzulának tekinthető XXX. cikk mellett egyéb helyeken is megfogalmazódik a hozzájárulás követelménye, addig a Szlovák Köztársaság Alkotmánya meglehetősen kurtán fogalmaz: alapnorma szintjén mindössze az adók létezését deklarálja. Minőségre vonatkozó értékítélet megfogalmazására azonban

${ }^{27}$ Art. 1-2. §. 
természetesen nem adhat okot ez a különbségtétel, noha az eltérés - mennyiségi értelemben legalábbis - meglehetősen szembetünő.

Az adóeljárás elveinek vizsgálata a fentiekhez hasonló eredményt mutat: a magyar szabályok ugyanis e tekintetben is lényegesen hosszabbak és részletesebbek. Számos olyan alapelv van azonban a szlovák és a hazai adóeljárásban, amely mindkét állam törvényében megfogalmazásra került. Természetesen eltérő szövegezéssel, de hasonló tartalommal jelenik meg mindkét jogszabályban az együttmüködési és tájékoztatási kötelezettség, a rendeltetésszerủ joggyakorlás követelménye, a megkülönböztetés tilalma, vagy éppen az adóhatóság eszközeit erősítő eljárási elv, mely szerint a valódi tartalomnak megfelelően vehetik figyelembe a hatóságok az ügyleteket.

A párhuzamosan megfogalmazott elvek minden esetben részletesebben kerülnek kifejtésre a magyar Art.-ben, illetve számos olyan alapelv is megjelenik hazánk adóeljárásában, amely érdemben többletként értelmezhető. Az adóalanyok érdekében megfogalmazott alapelvként a méltányosság elve nevesíthető, amely mellett az adótartozás mérséklése és fizetési könnyítés is az adózók védelmében került a szabályozásba. A becslési eljárás, a jogellenes ügyletekre is kiterjedő adózás, illetőleg a nemzetközi ügyletekre megfogalmazott ,adókiterjesztés” viszont mind a hatóság (az adóztató közhatalom, végső soron tehát maga az állam) javára fogalmaznak meg jogosultságokat. Ezek az elvek mind az adóeljárás, vagyis az állami bevételek beszedésének eredményességét mozdítják elő. A szabályozás ilyen módon való megfogalmazásának szükségessége és indoka igen messzire vezető gondolatokat ébreszthet, mely során feltehetőleg egyéb, az adómorált, az adófizetési hajlandóságot érintő kérdések értékelése is tényezőként merülhet fel.

Adózásról, közterhekről folytatott diskurzus során bizonyosan felmerül ugyanis az adók és az adófizetés társadalmi megítélése is, végezetül tehát néhány gondolatot e helyütt is szükséges szentelni annak. Tény, hogy a fiskális rendszerhez való társadalmi hozzájárulás egyik fő kérdése az adózási morál jelensége. Tekintettel arra, hogy a közteherviselés a társadalom tagjaira terhet ró, lényegében minden korban és társadalomban felmerül az adózási fegyelem kérdése, annak mértéke és jellege azonban változó. Az adó meg nem fizetése, a kötelezettség negligálása mértékében, vagyis számszerủen - és egyfajta fokozati skálán is ${ }^{28}$ - kirajzolható minden adóztató hatalommal élő állam esetében.

${ }^{28}$ Fokozati skála alatt itt az adózással kapcsolatos, azt elutasító (azzal visszaélő) magatartások súlyossága értendő. Ez ugyanis a fizetési kötelezettség egyszerủ elmulasztásától egészen a büntetőjogilag is értékelendő - sokszor igen bonyolultan megvalósított - költségvetési csalásig terjedhet. 
Az adófizetési hajlandóság eltéréseinek vizsgálata során, annak okait vizsgálva noha többféle teoretikus válasz adható rá - arra juthatunk, hogy az az állami legitimitás hiátusával magyarázható. Azokban az országokban ugyanis, ahol alacsony a társadalomnak a politikai rendszerbe vetett bizalma, a költségvetés jellemzően hiánnyal küzd. Alacsony legitimitás mellett ráadásul az állami közpénzügyi rendszer bevételi és kiadási oldala is hozzájárul a hiány kialakulásához: a bevételi oldalon a nagyobb az adókerülésre való hajlam, míg a kiadási oldalon a populista politikára való kísértés, valamint a strukturális reformokhoz szükséges konszenzus kialakításának nehézsége növeli az egyensúlytalanságot. ${ }^{29}$

Az adójogi jogkövetés helyzete több mint az adózó és az adóhatóság belső ügye. Ha ugyanis az egyén felől közelítjük meg a kérdést, megállapítható, hogy a negatív jogkövetési attitüd (vagyis az adó be nem fizetése), a harmadik személyek, azaz a társadalom többi tagja vonatkozásában nyilvánvalóan az adóterhek növekedésével jár. Ennek oka, hogy az egy före eső adóterhek és az állam azon költségei, melyek az adók behajtásával járnak, közvetetten beépülnek minden adózó költségeibe. Leegyszerüsítve tehát elmondható, hogy a nem fizetők adóterheit végeredményben azok fizetik meg, akik az adójogszabályokat betartják. ${ }^{30}$

Az adózás tehát a modern társadalom szinte szükségszerủ velejárója. Mára az állami szerepvállalás olyannyira kiterjedt, hogy anélkül talán elképzelhetetlen a mindennapi élet. A szociális biztonság, egészségügyi ellátórendszer, az állami oktatási hálózat mellett számos állami szinten biztosított szolgáltatást veszünk igénybe, melyek hatalmas és folyamatos anyagi erőforrások meglétét igénylik. Ezen erőforrások legjelentősebb hányadát a közterhekből befolyó pénzeszközök begyüjtése és koncentrációja biztosítja. Az egyes államok adórendszerére és főként adóeljárási szabályaira pedig tagadhatatlanul hatást gyakorol a helyi adómorál, hiszen annak jellege az adóbevételek teljesülésének eredményességét alapvetően képes meghatározni.

\section{Irodalomjegyzék}

Adams, Charles [2001]: For Good and Evil - The Impact of Taxes on the Course of Civilization. Madison Books.

Árendás Csaba-Dudás Tamás -Illés Gábor-Szinek Kénesy Marianna [2006]: A szlovákiai adóreform 2004-ben - a 19\% egy éve. Polgári Szemle, 2. sz., 3. o.

${ }^{29}$ Györffy [2007], 274. o.

${ }^{30}$ Szilovics [2003], 10. o. 
Balláné Nagy Katalin [2006]: A szlovákiai adóreform jellemzői, következményei, pozitív és negatív hatásai, valamint magyarországi vonatkozásai. EU Working Papers, 2006/4.

Bihari Mihály [2007]: A közterhekhez való hozzájárulás alkotmányos alapjai. In: Liber Amicorum Ünnepi előadások és tanulmányok Harmathy Attila tiszteletére. ELTE ÁJK Polgári Jogi Tanszék, Budapest.

Cserne Péter [2009]: 70/I. § Közteherviselés. In: Jakab András (szerk.): Az Alkotmány kommentárja. Századvég Kiadó, Budapest.

Erdős Éva [2011]: A közteherviselés elvének kiterjesztő értelmezése az európai adóharmonizáció tükrében. Miskolci Jogi Szemle, 6. évfolyam (különszám).

Földes Gábor [2007]: Az adótan és az adójog általános része. In: Simon István (szerk.): Pénzügyi jog I. Osiris Kiadó, Budapest.

Györffy Dóra [2007]: Társadalmi bizalom és költségvetési hiány. Közgazdasági Szemle, LIV. évf., 3. sz., 274-290. o.

Juhász István [é.n.]: Az adózás története. Letöltve: http://5mp.eu/fajlok/msc/adotortenelem_2_ www.5mp.eu_.pdf, (2017.08.25.).

Juhász István [2014]: Miért és hogyan adóztattak a történelem során? Letölthető: http://ado.hu/rovatok/ ado/miert-es-hogyan-adoztattak-a-tortenelem-soran-i-resz, (2017.08.25.).

Kaffka Margit [2013]: Szlovákia adózási rendszere. Adó szaklap - Nemzetközi adózás. Elérhető: http:// okosteuer.hu/wp-content/uploads/2014/01/nemzetk\%C3\%B6zi_adozas.pdf, (2017.08.25.).

Klicsu László [2011] Adalékok a közös teherviselés eredetéhez és alapjaihoz. Rubicon, 2011-2012. Elérhető: http://www.rubicon.hu/magyar/oldalak/adalekok_a_kozos_teherviseles_eredetehez_ es_alapjaihoz/, (2017.08.25.).

Marczali Henrik (szerk.) [1900]: Nagy Képes Világtörténet. IV. kötet: A népvándorlás kora. III. fejezet: Az iszlám. Elektronikus kiadás (Magyar Elektronikus Könyvtár), Arcanum Adatbázis Kft. Elérhető: http://mek.oszk.hu/01200/01267/html/04kotet/04r10f03.htm, (2017.08.25.).

Méder Zsombor Zoltán - Simonovits András - Vincze János [2012]: Adómorál és adócsalás - társadalmi preferenciák és korlátozott racionalitás. Közgazdasági Szemle, LI X. évf., 10. sz., 1086-1106. o.

Meravý, Tomáš [2012]: Tax Reforms in Slovakia: A story of never-ending experiments? Elérhető: http:// visegradrevue.eu/tax-reforms-in-slovakia-a-story-of-never-ending-experiments/ (2017.08.25.).

Molnár Gábor Miklós [2011]: Az adócsalás a költségvetési csalásban. Budapest, HVG-Orac.

Simon István [2011]: A közpénzügyek szabályozása az alkotmányban. Pázmány Law Working Papers, 2011/16.

Smith, Adam [1776]: An Inquiry into the Nature of the Wealth of Nations [A nemzetek gazdagsága - e gazdagság okainak és természetének vizsgálata]. London.

Szilovics Csaba [2003]: Csalás és jogkövetés az adójogban. Gondolat Kiadó, Budapest.

Tomcsányi Móric [1940]: Magyarország közjoga. Királyi Magyar Egyetemi Nyomda, Budapest. 